\title{
Effect of different media and timing factor on rooting of olive (Olea europea) through air layering
}

\author{
Azmat Ali Awan ${ }^{1}$, Mohammad Ilyas²*, Azaz Shakir ${ }^{3}$, Muhammad \\ Saleem Khan ${ }^{4}$, Nasim Ahmad ${ }^{4}$, Manzoor Ahmad ${ }^{5}$, Gohar Ayub², Gulzar \\ Ullah $^{2}$ and Farzana Begum ${ }^{2}$ \\ 1. Pakistan Oilseed Development Board, Tarnab Farm Peshawar-Pakistan \\ 2. Department of Horticulture, The University of Agriculture Peshawar-Pakistan \\ 3. Department of Botany Islamia College Peshawar-Pakistan \\ 4. Agriculture Research System Khyber Pakhtunkhwa-Pakistan \\ 5. Department of Agriculture Bacha Khan University Charsadda-Pakistan \\ *Corresponding author's email: Ilyas_swati88@yahoo.com \\ Citation \\ Azmat Ali Awan, Mohammad Ilyas, Azaz Shakir, Muhammad Saleem Khan, Nasim Ahmad, Manzoor Ahmad, \\ Gohar Ayub, Gulzar Ullah and Farzana Begum. Effect of different media and timing factor on rooting of olive (Olea \\ europea) through air layering. Pure and Applied Biology. Vol. 6, Issue 4, pp1126-1131. \\ http://dx.doi.org/10.19045/bspab.2017.600121
}

Received: 28/05/2017 Revised: 18/08/2017 Accepted: 05/09/2017 Online First: 09/09/2017

\section{Abstract}

This study was undertaken to investigate the effect of different media and timing factor on rooting of olive (Olea europaea) plant through air layering at ARI, Tarnab Peshawar during 2011. Layering was done at different times i.e. $16^{\text {th }}$ June, $6^{\text {th }}$ July and $26^{\text {th }}$ July i.e. at intervals of 20 days. Different media i.e. sand, silt, F.Y.M and sawdust were used for layering. In the experiment, there were five air-layers in one treatment and 60 layers in one replication. The experiment was laid out in a randomized complete block design with split plot arrangement having three replications and four treatments in each plot. Timing factor was allotted to main plot while various media were kept in sub plots. According to the experimental results, maximum days to root appearance (30) and number of roots (7.8) were obtained in sand media, while maximum root diameter $(0.16 \mathrm{~cm})$, root length $(3.86 \mathrm{~cm})$ and maximum plant survival $(60 \%)$ were obtained in silt media. On the other hand, minimum number of days to root appearance (15), number of roots $(2.4)$, root diameter $(0.03 \mathrm{~cm})$, root length $(1.37 \mathrm{~cm})$ and minimum plant survival $(6.67 \%)$ were recorded in media of FYM. Similarly, maximum number of days to root appearance (37), root length $(3.44 \mathrm{~cm})$, root diameter $(0.13 \mathrm{~cm})$ were obtained in air layering made on 16 June, while maximum number of roots (7.3) and plant survival (46.67\%) were noted in layers made on 6 July, while minimum number of days to root appearance $(15)$, root diameter $(0.11 \mathrm{~cm})$, root length $(2.59 \mathrm{~cm})$ and plant survival $(31.67 \%)$ were recorded in layers made on 26 July, while minimum number of roots (4.2) was noted in layer made on 16 June. Therefore, there was a distinct effect of the various media and layering timings on the rooting of olive plants.

Keywords: Air Layering; Effect; Media; Olive; Olea europea; Rooting; Timings

\section{Introduction}

Olive (Olea Europaea), an evergreen and slow growing tree having more than 1000 years age. It is one of the most important member of the family Oleaceae family and is cultivated edible oil and its fruits. Olives 
have not been traditionally grown in Pakistan for the edible oil production, although few grooves existed both in the plain and hilly areas; the oldest cultivation being established in the 1970's [1]. It is propagated both through sexual and asexual means. Propagation of olive through sexual mean is not usually recommended, because seedlings are not true to type and it will take a lot of time to bear fruits. Asexual or vegetative propagation methods are the most widely used commercially for propagation. Asexual propagation methods include Cutting, Budding, Grafting and Air-layering [2].

Air-layering is usually done in the months from June-August. Branches from welldeveloped trees, free from pests and diseases are selected for air-layering. A branch of 5$10 \mathrm{~mm}$ in diameter is selected and bark of $1 / 2-$ 1 inch is removed, covered with garden soil and any other rooting medium and then wrap with polythene film. When a good ball of roots has formed, the branch is then cut off below the wrapped soil after which is generally placed in larger tube or pot to become more firmly established before being set out permanently [2]. [3] air layered one year old shoots on several dates between July-November and observed rooting percentage and establishment (in three cultivars), survival after transplanting (in two cultivars) and the effect of defoliation on nursery establishment. They got successful layering between mid July and early October and recommended defoliation to retain 20 leaf lets at transplanting.

[4] studied propagation in sub tropical fruit trees by air layering. He girdled the branch to be air layered and immediately wrapped the girdled portion with a prepared peat moss bag. [5] studied the effect of pruning and the survival of detached rooted air layers in litchi. Sixty days after air layering the detached plants were pruned heavily, moderately or lightly and were then potted and kept in shade. Heavy pruning gave the best plant survival of $72.7 \%$ compared with moderate $(45.4 \%)$ and light pruning (36.6\%). [6] recommended air layered litchi trees for orchard establishment in 10 years trials; they compared marcoted and grafted trees. Root growth was much better with grafted trees, but differences in tree growth were slight after four years. They recommended that marcotted tree should be kept in the nursery for at least six months after removal from the parent trees. [7] also studied soil, soil/sand and soil/FYM mixtures, cutting or ringing the layers and detachment from the mother plant after 3 or 4 months of layering with a half cut followed by detachment 15 days later or complete detachment after 3 or 4 months. They reported that 1:1 soil/sand mixture was the best and that ringing gave better results than cutting.

\section{Materials and methods}

To evaluate the reponse of different media and timing factor on rooting of olive plant through air layering an experiment was conducted at Pakistan Oilseed Development Board (PODB), (Tarnab) Peshawar Pakistan during the year 2011. Layering was done at different times interval $16^{\text {th }}$ June, $5^{\text {th }}$ July and $26^{\text {th }}$ July i.e. at regular intervals of 20 days. In order to initiate rooting in olive, branches were wounded by complete removal of ring bark just below the buds in the month of June and July. Different media then surrounded the injured portion i.e. sand, silt, F.Y.M. sawdust held in the place by heavy wrapping of burlap with plastic sheet. When a good ball of roots had formed, the branches were cut off below the media and were placed in beds to become more firmly established before being set out permanently.

In the experiment, there were five air-layers in one treatment and 60 layers in one replication Replicated three times. The experiment was laid out in a randomized 
complete block design with split plot arrangement having three replications and four treatments in each plot. Timing factor was allotted to main plot while various media were kept in sub plots. Four media containing sand, silt, F.Y.M and sawdust were used. All other agronomic practices were kept uniform for all the treatments during the course of experiment.

The data were recorded on the following parameters:

\section{Days to root appearance}

Total number of days to root appearance and their averages was calculated after the date of air-layering and media treatments were recorded in each treatment.

\section{Number of roots plant $\mathbf{t}^{-1}$}

Number of roots plant $^{-1}$ data was recorded by cutting air layered shoots and the media attached with roots were removed and washed with water and the number of root per air layered shoot/plant were counted and the average was worked out.

\section{Root length (cm)}

The length of roots was measured from base to the tips of roots. The averages were calculated after recording the roots measurement in each replication.

\section{Root diameter (cm)}

The root thickness of primary root part was measured with the help of vernier caliper in centimeter and the averages were calculated for statistical analysis.

\section{Percent survival of plant}

At the end of experiment, the plants were counted; survival plant $\%$ ages were recorded by the following formula:
Percent plant survival $=\underline{\text { Number of survived Plants } x}$ $\underline{100}$ Total number of plants

\section{Results and discussion \\ Number of days to root appearance}

Data regarding days to root appearance are reported in Table 1. Statistical analysis of the data revealed that different timing of airlayering significantly affected days to root appearance of olive layering, while various media and interaction between the media and different timing did not significantly affect days to root appearance. According to the Table 1 maximum number of days to root appearance (30) was taken by the airlayering made in sand media followed by silt (26), while minimum numbers of days (15) to root appearance were recorded by media FYM. In case of timing, higher days to root appearance (37) were taken by airlayering which were made on 16 June while lesser days to rooting (15) were recorded by the air-layering made on 26 July. More days to rooting were taken by air-layering that were made on $16^{\text {th }}$ June of 2011 while fewer days to root appearance were recorded in the air-layering made on $26^{\text {th }}$ July of 2011. It might be due to maximum rainfall and water availability in the month of July which resulted in an early root appearance, whereas in June the less rainfall and higher temperature resulted in stress condition for the olive air-layering that took more days to root appearance. The results were confirmed by the work of [8] who reported that the month of July is the best for air-layering. All the media had statistically similar response to the days to root appearance. 
Table 1. Mean data for days to rooting, Number of roots, Root diameter $(\mathrm{cm})$, Root length (cm) and plant survival (\%) of olive through air layering

\begin{tabular}{|l|l|l|l|l|l|}
\hline Media & $\begin{array}{l}\text { Days to } \\
\text { rooting }\end{array}$ & $\begin{array}{l}\text { Number of } \\
\text { roots }\end{array}$ & $\begin{array}{l}\text { Root diameter } \\
(\mathbf{c m})\end{array}$ & $\begin{array}{l}\text { Root length } \\
(\mathbf{c m})\end{array}$ & $\begin{array}{l}\text { Plant } \\
\text { survival (\%) }\end{array}$ \\
\hline Sand & 30 & $7.8 \mathrm{a}$ & $0.14 \mathrm{a}$ & $3.51 \mathrm{a}$ & $51.11 \mathrm{ab}$ \\
\hline Silt & 28 & $4.9 \mathrm{bc}$ & $0.16 \mathrm{a}$ & $3.86 \mathrm{a}$ & $60.00 \mathrm{a}$ \\
\hline FYM & 15 & $2.4 \mathrm{c}$ & $0.03 \mathrm{~b}$ & $1.37 \mathrm{~b}$ & $6.67 \mathrm{c}$ \\
\hline Sawdust & 26 & $6.4 \mathrm{ab}$ & $0.15 \mathrm{a}$ & $3.79 \mathrm{a}$ & $31.11 \mathrm{~b}$ \\
\hline LSD & $\mathbf{N S}$ & $\mathbf{2 . 7 9}$ & $\mathbf{0 . 0 5 2}$ & $\mathbf{1 . 6 9}$ & $\mathbf{2 4 . 4}$ \\
\hline Time & \multicolumn{5}{|l|}{} \\
\hline $16^{\text {th }}$ June & $37 \mathrm{a}$ & $4.2 \mathrm{~b}$ & 0.13 & 3.44 & 33.33 \\
\hline $06^{\text {th }}$ July & $22 \mathrm{~b}$ & $7.3 \mathrm{a}$ & 0.12 & 3.37 & 46.67 \\
\hline 26 $6^{\text {th }}$ July & $15 \mathrm{~b}$ & $4.6 \mathrm{~b}$ & 0.11 & 2.59 & 31.67 \\
\hline LSD & $\mathbf{1 1 . 8 8}$ & $\mathbf{2 . 0 0}$ & $\mathbf{N S}$ & $\mathbf{N S}$ & NS \\
\hline
\end{tabular}

\section{Number of roots per air-layering}

Data regarding number of roots are presented in Table 1. Perusal of the data showed that various media and different timing of layering significantly affected number of roots of olive layer, however the interaction between the two factors were not significant. Mean value of the data indicated that maximum number of roots (7.8) was observed in the air-layering in sand followed by saw dust (6.4), while minimum number of roots (2.4) was recorded in FYM. In case of timing, significantly higher number of root (7.3) was observed in air-layering which were made on 6 July while lower number of roots (4.2) was recorded in the air-layering made on 16 June. Sand media is porous and hence proficient of good root growth and development thus resulted in higher number of roots in olive air-layering. More number of roots in early July may be due to the favorable temperature whereas lower number of roots in month of June might be due to high temperature which might have increased the rate of net respiration of the plant. As far as timing is concerned more number of roots was observed in the layer in the month of July. The results are supported by Ahmad [9] who studied propagation in different plants.

\section{Root diameter (cm)}

Data regarding root diameter are shown in Table 1. Analysis of the data showed that various media significantly affected root diameter of olive air-layering, while the effect of timing and their interaction were not significant. Mean value of the data revealed that maximum root diameter $(0.16$ $\mathrm{cm}$ ) was recorded in the air-layering done in silt followed by saw dust $(0.15 \mathrm{~cm})$, while minimum root diameter $(0.03 \mathrm{~cm})$ was recorded in FYM. In case of timing, higher root diameter $(0.13 \mathrm{~cm})$ was observed in the air-layering which were made on 16 June, while lower root diameter $(0.11 \mathrm{~cm})$ was recorded in the air-layering made on 26 July. Silt media have more nutrients and also provided favorable condition for root growth which ultimately resulted in highest diameter. Our results are in agreement with [10] who observed highest root diameter of $0.23 \mathrm{~cm}$ in silt media.

\section{Root length (cm)}

Data regarding root length are reported in Table 1. Statistical analysis of the data indicated that root length of olive airlayering were significantly affected by various media, while the effect of different timing of layering and the interaction between the two factors were not significant. Maximum root length $(3.86 \mathrm{~cm})$ was 
recorded in the air-layering done in silt followed by saw dust $(3.79 \mathrm{~cm})$, while minimum root length $(1.37 \mathrm{~cm})$ was recorded in FYM. Higher root length (3.44 $\mathrm{cm})$ was observed in the air-layering which were made on 16 June, while minimum root length $(2.59 \mathrm{~cm})$ was noted in the airlayering made on 26 July. As silt is abundant in nutrients, consequently resulted in higher root diameter might contributed to superior root length. Lower root length and width in farm yard manure might be due to its toxic effect on the air-layering as FYM was partially decomposed. The silt does have more pore spaces as compared to the other soil and hence, more nutrients were available. This was followed by the saw dust media that's why silt showed better results. Similar results have also been reported by Mathad and Nalwadi [10].

\section{Plant survival percentage}

Perusal of the data in Table 1 showed that various media significantly affected survival of olive layers, while different timing and the interaction between media and timing had not significantly affected the plant survival percentage. Mean value of the data showed that maximum plant survival $(60 \%)$ was observed by the layer done in silt followed by sand $(51.11 \%)$, while minimum plant survival $(6.67 \%)$ were recorded by FYM. However higher plant survival (46.67 $\%)$ was found in the layers made on $6^{\text {th }} \mathrm{July}$, while minimum plant survival (31.67\%) was recorded by the layer made on $26^{\text {th }}$ July, 2011. Silt media resulted in superior root length and root diameter consequently resulted in high plant survival [10]. However, minimum plant survival was recorded in FYM. The poorest performance of rooted cuttings in FYM soil might have been due to the nutritionally poor medium that resulted in the minimum values of all the parameters under study. [11] reported that decomposed organic material improved soil fertility by increasing soil aeration, water holding capacity and water infiltration and lower surface crusting. The lesser growth in FYM also might have been due to the minimum number of roots and shoots that reduced the rate of photosynthesis, thereby reducing the plant growth and survival.

\section{Conclusion and recommendation}

In light of the above results, it is concluded that the days to rooting, number of roots per air-layering were the highest under the airlayering done in sand medium and lowest under the FYM medium. More days to rooting were taken by air-layering that were made on June 16, 2011. The number of roots per air-layering was highest at the July 6 , 2011. The root length and the percent plant survival were the highest when the air layering was done in silt medium. Therefore, the media of sand and silt are the best for air layering and in addition the date of July 6 is the optimum timing for the air layering process.

Air layering done in silt and Sand media in the month of late June to mid-July was recommended for maximum survival.

\section{Authors' contributions}

Conceived and designed the experiments: AA Awan, Performed the Experiments: AA Awan, Analyzed the Data: G Ayub, Contributed reagents/ materials/ analysis tools: A Shakir, Wrote the paper: M Ilyas.

\section{References}

1. Wilson P (1920). Manual of tropical and subtropical fruits. MacMillan publishing Co., Inc. New York pp. 321-323.

2. Kanwar JS \& Kahlon GS (1986). Propagation studies in litchi. $J$ Res Punjab Agric Univ 23(1): 33-39 (Hort. Absts. 1987, 057-05009).

3. Kadman A (1983). Propagation of subtropical fruit trees by air layering. M.Sc (Hons) Thesis 1997, Department of Horticulture, NWFP Agricultural University Peshawar. Agri Res 
Organization Bet Dagam, Israel 63(8): 1674-1678.

4. Sharafuddin AFM (1983). Effect of pruning on the survival of detached rooted air layers in litchi. Bangladesh. Hort 11(1): 39-40. (Hort. Absts. 1984, 054-0767).

5. Bolt LC \& Joubert AJ (1980). Air layered litchi trees recommended for orchard establishment. Information bulletin, citrus and subtropical fruit research institute No. 92: 4-5.

6. Malik MN \& Maqbool M (1977). Studies on the effect of various physical treatments on the successful establishment of litchi plants through layer age. J Agric Research Pakistan 15(4): 321-327. (Hort Absts 1978, 05705662).
7. Ray A (1952). An experiment on performance of rooting through different media in litchi. Report Fr Res Sch. Bihar.

8. Awan AA, Iqbal A, Rehman J \& Idris G (1999). Response of Olive hard wood cutting to different Growth media and basal injuries for propagation Asian $J$ Plant Sci 2 (12): 883-886.

9. Ahmad S (1994). Plant propagation. National Book Foundation, Islamabad, Pakistan. pp. 185-186.

10. Mathad MC \& Nalwadi UG (1989). Rooting ability of some important ornamental climbers. South Indian Hort 37(5): 307 - 308.

11. Simmonds NW (1976). Evolution of Crop Plants. Longman Group Ltd. London pp. 219-221. 